\title{
Theoretical, methodological and analytical aspects of ethnographic research in obstetric nursing: an integrative review*
}

\author{
Aspectos teóricos, metodológicos e analíticos de pesquisas \\ etnográficas em enfermagem obstétrica: revisão integrativa \\ Aspectos teóricos, metodológicos y analíticos de investigaciones \\ etnográficas en enfermería obstétrica: revisión integrativa
}

How to cite this article:

Belém JM, Pereira EV, Rebouças VCF, Borges JWP, Pinheiro AKB, Quirino GS. Theoretical, methodological and analytical aspects of ethnographic research in obstetric nursing: an integrative review. Rev Esc Enferm USP. 2020;54:e03547. DOI: http://dx.doi.org/10.1590/S1980-220X2018034203547

\section{Jameson Moreira Belém ${ }^{1}$ \\ Emanuelly Vieira Pereira ${ }^{1}$ \\ Vitória de Cássia Félix Rebouças ${ }^{1}$ \\ José Wicto Pereira Borges ${ }^{2}$ \\ Ana Karina Bezerra Pinheiro ${ }^{3}$ \\ Glauberto da Silva Quirino ${ }^{1}$}

* Extracted from the dissertation: "Cuidado de enfermagem obstétrico transcultural: práticas profissionais e experiências maternas no parto institucionalizado", Programa de Pós-graduação em Enfermagem, Universidade Regional do Cariri, 2017.

${ }^{1}$ Universidade Regional do Cariri, Departamento de Enfermagem, Crato, CE, Brazil.

${ }^{2}$ Universidade Federal do Piauí, Departamento de Enfermagem, Teresina, PI, Brazil.

${ }^{3}$ Universidade Federal do Ceará, Departamento de Enfermagem, Fortaleza, CE, Brazil

\begin{abstract}
Objective: To characterize ethnographic research in the area of obstetric nursing regarding its theoretical, methodological and analytical aspects. Method: An integrative review performed in the MEDLINE ${ }^{\circledR}$, LILACS, BDENF and CINAHL databases, as well as the SciELO virtual library. Results: Thirty (30) articles formed the analytical corpus after screening and reading the primary references in full. The most used methods were ethno-nursing, ethnography and institutional ethnography; the immersion time in the field ranged from 12 visits to 48 months occurring in institutional contexts. The main data collection techniques were observation, individual interviews and training guides for ethno-nursing. The data were organized as themes and subthemes, analyzed through the ethno-nursing analysis guide, implementing the Theory of Diversity and Universality of Cultural Care as theoretical reference. Conclusion: Ethnographic studies in the area of obstetric nursing are within the scope of microethnographies and are operationalized based on theoretical-methodological nursing references, being useful to analyze the complexity of phenomena involving obstetric nursing care, and focusing on the etic (professional) and emic (women) perspectives.
\end{abstract}

\section{DESCRIPTORS}

Nursing Care; Obstetric Nursing; Women's Health; Culture; Anthropology, Cultural; Review. 


\section{INTRODUCTION}

Health and disease cannot be merely thought of as a consequence of pathophysiological factors, but as complex phenomena signified by culture and shared between groups, and should not be dissociated from social determinants. Therefore, the use of anthropological methods such as ethnography is a possibility to access the sociocultural structure which models the health-disease relationship, describing the experiences and insertion of people in this process ${ }^{(1)}$.

Culture and social relations are implicated within this context as determinants of nursing care ${ }^{(2)}$. The understanding of this theoretical and practical relationship in nursing began in the 1960s through a method called "ethno-nursing", inspired by the ethnographic method ${ }^{(3)}$. Ethnography has been used in nursing as a methodological foundation in scientific research to apprehend and analyze specific lifestyles or care patterns expressed in a given culture ${ }^{(2-3)}$.

This need also presents itself specifically in obstetric nursing, as pregnancy, childbirth and delivery are vital phenomena signified by culture. Thus, obstetric nursing care should be based on knowledge of beliefs, values, practices and cultural meanings and around the pregnancy, childbirth and puerperium processes ${ }^{(4-6)}$. The ethnographic perspective in this care can contribute to professional practices, interaction with users, families or communities, humanization of the pregnancy, childbirth and delivery processes and to care comprehensiveness ${ }^{(2,6)}$.

In analyzing the national and international scientific production in the obstetric nursing area, it was noticed that the researchers used ethnography as a methodological reference in conducting their investigations ${ }^{(7)}$. A review study ${ }^{(7)}$ seeking to identify how ethnography was applied in nursing from 2009 to 2013 analyzed the dimensions related to the health-disease process addressed in these studies, however without describing how the method was employed or specifying a nursing area.

In addition, the methodological procedures for conducting ethnographic studies are not accurately described and do not provide operational guidelines; moreover, its links with understanding the phenomenon are poorly explained ${ }^{(8-9)}$. Thus, recognizing that ethnographic methods constitute a complex methodological strategy and their use represents an arduous task, studying them may pave the way for applications which enable understanding the complexity of the phenomena involved in obstetric nursing care.

Thus, the objective of this study was to characterize ethnographic research in the obstetric nursing area regarding theoretical, methodological and analytical aspects. It is believed that the use of ethnography and theoretical-methodological references based on an anthropological-cultural perspective can contribute to constructing theoretical-conceptual contributions, as well as ethical, aesthetic, epistemological and philosophical assumptions to guide the actions and ground practices of obstetric nursing care.

\section{METHOD}

\section{STUdY DESIGN}

This is an integrative review implementing a methodological course consisting of the following steps: identifying the guiding question; establishing inclusion and exclusion criteria; categorization (extracting, organizing and summarizing information); evaluating included studies; interpreting the results; presenting the review ${ }^{(10)}$.

\section{IDENTIFYING THE GUIDING QUESTION}

The following guiding question was formulated in the first stage: What are the theoretical, methodological and analytical characteristics of ethnographic research conducted in the obstetric nursing area?

\section{ESTABLISHING THE INCLUSION AND EXCLUSION CRITERIA}

Operationalizing the research began with defining the inclusion criteria: research articles with a qualitative approach in obstetric nursing (involving care provided to women before, after and during childbirth) and their contribution to ethnographic methods, published in English, Portuguese, or Spanish. The following studies were excluded: those implementing a mixed approach (quantitative-qualitative); involving adolescents, considering that the social, economic, cultural and historical issues which involve reproductive aspects in adolescence are complex and multifactorial ${ }^{(11)}$; theses; dissertations; experience reports; or those which were not available in full text for download. No time frame was established for the inclusion of articles in order to cover the largest number of publications.

\section{DATA SOURCES AND SEARCH STRATEGY}

Data collection was performed in 2017 in a paired manner through the CAPES journal portal, in the Medical Literature Analysis and Retrieval System Online $\left(\mathrm{MEDLINE}^{\oplus}\right)$ databases, Literature Latin American and Caribbean Health Sciences (LILACS), Nursing Database (BDENF), Cumulative Index to Nursing and Allied Health Literature (CINAHL) via EBSCO Information Services, and the Scientific Electronic Library Online (SciELO) virtual library using the advanced search method.

An association of six subject descriptors from the Medical Subject Headings (MeSH) of the National Library of Medicine (NLM) and National Institutes of Health (NIH) was used in the search, five of which were controlled ("obstetric nursing", "nursing", "culture", "anthropology" and "anthropology cultural") and two were not controlled, namely a synonym ("ethnography") and keyword ("ethnonursing") in order to increase the scope of the revision. The search strategy implemented to perform pairwise crossing used the Boolean operator "AND" to associate the descriptors.

Thus, 636 primary references were initially identified in the selected databases/virtual library (Chart 1). 
Chart 1 - References found with respective crossings ( $n=636), 2017$.

\begin{tabular}{|c|c|c|c|c|c|c|}
\hline Search strategies & SciELO & BDENF & LILACS & MEDLINE® & CINAHL & Total \\
\hline "Obstetric nursing" AND "culture" & 7 & 16 & 19 & 69 & 101 & 212 \\
\hline "Obstetric nursing" AND "anthropology" & 2 & 9 & 10 & 4 & 4 & 29 \\
\hline $\begin{array}{l}\text { "Obstetric nursing" AND "anthropology } \\
\text { cultural" }\end{array}$ & 1 & 9 & - & 4 & 3 & 17 \\
\hline "Obstetric nursing" AND "ethnography" & 2 & 8 & 8 & 3 & 8 & 29 \\
\hline "Obstetric nursing" AND "ethnonursing" & 1 & 2 & - & - & 3 & 6 \\
\hline "Nursing" AND "ethnonursing" & 24 & 2 & 13 & 97 & 207 & 343 \\
\hline Total & 37 & 46 & 50 & 177 & 326 & 636 \\
\hline
\end{tabular}

SciELO: Scientific Electronic Library Online; BDENF: Base de Dados em Enfermagem; LILACS: Literatura Latino-Americana e do Caribe em Ciências da Saúde: MEDLINE®: Medical Literature Analysis and Retrieval System Online; CINAHL: Cumulative Index to Nursing and Allied Health Literature.

The articles were subjected to a screening process through subject analysis after the identification stage, which included reading the title and abstract and analysis according to the inclusion and exclusion criteria. Duplicate articles repeated between databases and among the selected ones were identified in this process, and a definitive selection of references eligible for full reading was performed.

The Preferred Reporting Items for Systematic Review and Meta-Analyzes (PRISMA) ${ }^{(12)}$ instrument was used to report the process of identification, screening, eligibility and inclusion of studies, as shown in Figure 1.

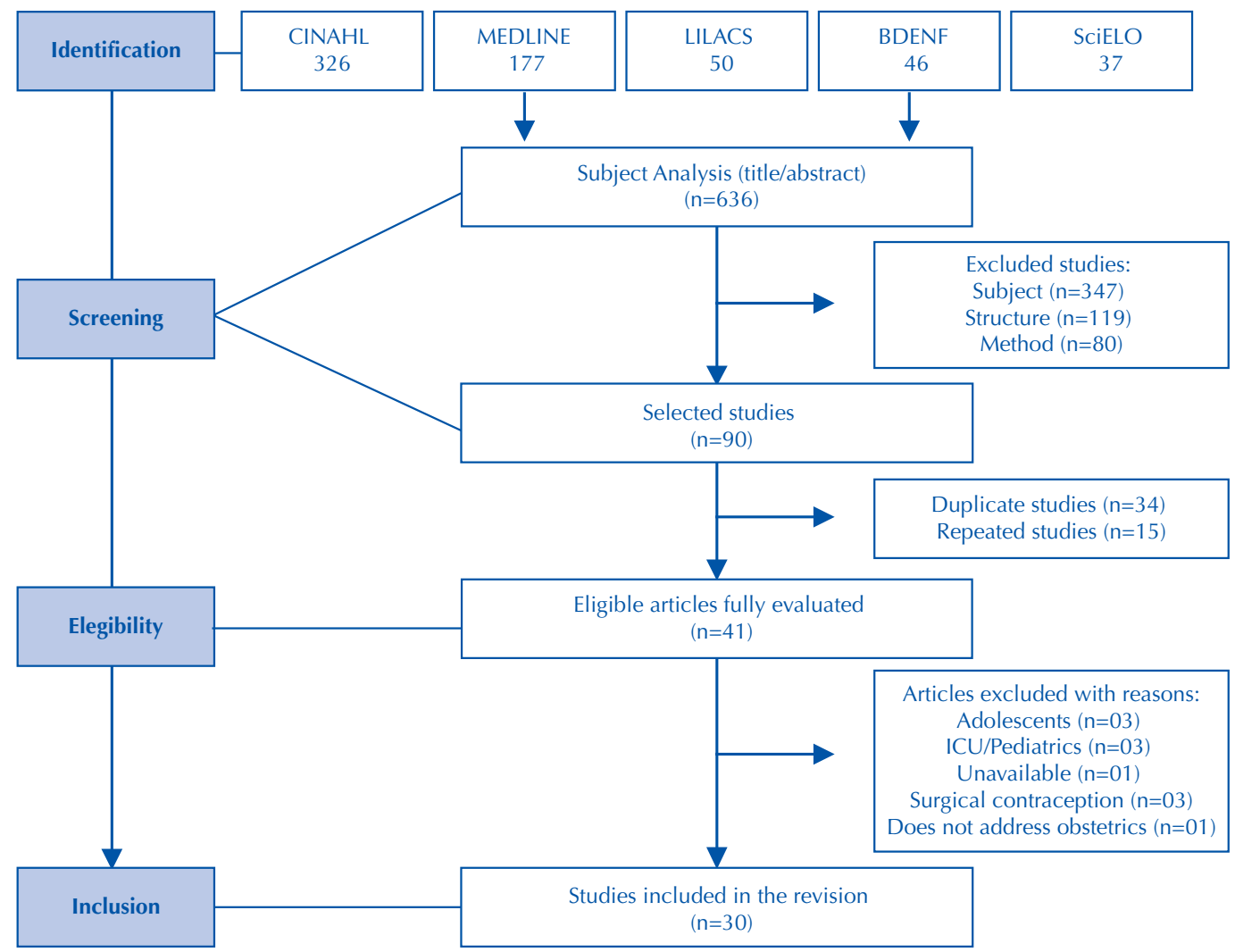

CINAHL: Cumulative Index to Nursing and Allied Health Literature; MEDLINE ${ }^{\circledR}$ : Medical Literature Analysis and Retrieval System Online; LILACS: Literatura LatinoAmericana e do Caribe em Ciências da Saúde; BDENF: Base de Dados em Enfermagem; SciELO: Scientific Electronic Library Online; ICU: Intensive Care Unit.

Figure 1 - Article search and selection process by crossing Medical Subject Headings (MeSH) terms via databases and virtual libraries.

All studies were double-checked by independent reviewers as a procedural strategy in order to ensure the quality of these steps and avoid selection bias. Evaluating the inclusion or exclusion of the studies had the previously established criteria and the guiding question as parameters. A third reviewer was assigned to repeat the reading process in situations of diverging opinions and issue a new review, aiming to ensure uniformity, validity and rigor to the inclusion process of studies in the review. Thus, the final sample consisted of 30 articles.

\section{EvaluATION OF THE INCLUDED STUDIES}

After selection, the methodological quality evaluation of the studies was performed based on the items of the Critical Appraisal Skills Program (CASP) instrument, which classifies articles into two categories: (A) good methodological quality and reduced bias (scores between six to 10 points); and (B) satisfactory methodological quality, but with increased risk of bias (with a score below 6 points) ${ }^{(13)}$. This process was performed by two evaluators without any information being exchanged between them. All articles included in the sample fell into 
category $\mathrm{A}$ in the sum of the scores of the two evaluators. It is noteworthy that there was no disagreement between the reviewers in the evaluation process, and so there was no need for a third reviewer.

\section{DATA EXTRACTION, ORGANIZATION AND SUMMARIZING PROCEDURES}

An instrument developed by the researchers for data extraction containing the variables of authorship, year, journal, source, location, methodological reference, definition of informants, locus, scenarios and research contexts, immersion process in the field, data collection techniques, organization of empirical data, data analysis, theoretical aspects, reproductive cycle periods, perspectives and dimensions of analysis, methodological rigor, reflexivity and ethical aspects was used.

\section{Data ANALYSIS AND PROCESSING}

The information was organized by similarities and divergences after coding procedures, and then reduced and electronically compiled in a Microsoft Office Excel ${ }^{\oplus}$ version 2013 spreadsheet and double-validated to eliminate possible errors and ensure reliability.

Data reduction method was used in the analysis process, which involved thorough reading and classification

techniques and subgrouping primary sources according to the approach and methodological aspects ${ }^{(14)}$.

This process enabled organizing the data in a logical structure, simplifying, summarizing, abstracting and systematically comparing the results from primary studies on the issue under study ${ }^{(14)}$, facilitating an interpretative analysis process and presenting the review in the form of a descriptive synthesis, charts and figures with further discussion of the findings in accordance with the scientific literature.

\section{ETHICAL ASPECTS}

It is justified to waive consideration by the Research Ethics Committee due to the fact that this study only uses data available in the public domain and without the involvement of human beings or which requires ethical confidentiality.

\section{RESULTS}

A presentation of the results of this review includes a brief characterization of the primary studies (summarized in Chart 2) and a subsequent descriptive synthesis of the theoretical, methodological and analytical aspects adopted in the conduct of ethnographic research.

Chart 2 - Characterization of ethnographic research in obstetric nursing.

\begin{tabular}{|c|c|c|c|c|}
\hline Authorship & Location & Research scenarios and contexts & $\begin{array}{l}\text { Immersion } \\
\text { in the field }\end{array}$ & CASP \\
\hline Bonadio $^{(15)}$ & São Paulo city, Brazil & Prenatal Service of a Philanthropic Institution & Not cited & A \\
\hline Woodward ${ }^{(16)}$ & Not informed & $\begin{array}{l}\text { Hospital and maternity hospital of a national health } \\
\text { service }\end{array}$ & 12 visits & A \\
\hline Berry $^{(17)}$ & Southwestern United States & $\begin{array}{c}\text { Prenatal public health clinic, a hospital and } \\
\text { households }\end{array}$ & 11 months & A \\
\hline Nahas and Amasheh ${ }^{(18)}$ & Western Sydney Area, Australia & Community & Not cited & A \\
\hline Morin et al. ${ }^{(19)}$ & United States Middle Atlantic Region & Maternal and child unit of a small community hospital & 12 months & A \\
\hline Angus et al. ${ }^{(20)}$ & Uninformed & \begin{tabular}{|l} 
Four community hospitals \\
\end{tabular} & 20 days & A \\
\hline Praça $\mathrm{a}^{(21)}$ & West zone of the municipality of São Paulo, Brazil & Community center and slum households & 19 months & A \\
\hline $\operatorname{Hoga}^{(22)}$ & São Paulo, Brazil & Child birth center & 5 months & A \\
\hline Jeneral and Hoga(23) & Sorocaba city, interior of São Paulo state, Brazil & Low income community & Not cited & A \\
\hline Medves and Davies ${ }^{(24)}$ & Ontario, Canada & Rural maternity hospital & Not cited & A \\
\hline Bezerra and Cardoso ${ }^{(25)}$ & Fortaleza, Ceará, Brazil & $\begin{array}{l}\text { Inpatient unit and obstetric center of public } \\
\text { maternity and households }\end{array}$ & 3 months & A \\
\hline Monticelli and Elsen ${ }^{(26)}$ & South region of Brazil & Collective unit of public maternity joint housing & 12 months & A \\
\hline Monticelli and Elsen ${ }^{(27)}$ & South region of Brazil & Collective unit of public maternity joint housing & 12 months & A \\
\hline Bezerra and Cardoso $^{(28)}$ & Fortaleza, Ceará, Brazil & Inpatient unit and public maternity obstetric center & 3 months & A \\
\hline Foster et al. ${ }^{(29)}$ & Dominican Republic & Reference hospital and maternity hospital & Not cited & A \\
\hline El-Nemer et al. ${ }^{(30)}$ & Egypt & Hospital and maternity & 3 months & A \\
\hline Kennedy and Lyndon ${ }^{(31)}$ & Northern California, United States & Northern California Urban Teaching Hospital & 24 months & A \\
\hline Leal and Rodríguez ${ }^{(32)}$ & Girardot City, Colombia & Hospital Prenatal Care Program & 3 months & A \\
\hline Bernal-Roldán et al. ${ }^{(33)}$ & $\begin{array}{l}\text { Suba and Ciudad Bolivar Localities, Bogota City, } \\
\text { Colombia }\end{array}$ & Households & Not cited & A \\
\hline MacKinnon $^{(34)}$ & $\begin{array}{c}\text { Cranbrook city, Western Province of British } \\
\text { Columbia, Canada }\end{array}$ & Rural Regional Hospital & 48 months & A \\
\hline MacKinnon $^{(35)}$ & $\begin{array}{c}\text { Cranbrook city, Western Province of British } \\
\text { Columbia, Canada }\end{array}$ & Rural Regional Hospital & 48 months & A \\
\hline Maia and Silva ${ }^{(36)}$ & Benjamin Constant City, Amazonas, Brazil & Ribeirinha community & 2 months & A \\
\hline Prieto and Ruiz ${ }^{(37)}$ & Tunja City, Boyaca Department, Colombia & Households & Not cited & A \\
\hline Tasçı-Duran and Sevil(38) & Bornova, İzmir Province Metropolitan District, Turkey & Family Health Center & 10 months & A \\
\hline Feyer et al. ${ }^{(39)}$ & Florianópolis, Santa Catarina, Brazil & Households & 8 months & A \\
\hline Lessa et al..$^{(40)}$ & Rio de Janeiro City, Brazil & Households & 6 months & A \\
\hline Lessa et al. ${ }^{(41)}$ & Rio de Janeiro City, Brazil & Households & 6 months & A \\
\hline Junges et al. ${ }^{(42)}$ & $\begin{array}{l}\text { North Region of Santa Maria City, Rio Grande do } \\
\text { Sul, Brazil }\end{array}$ & Urban community & 3 months & A \\
\hline Alves et al. ${ }^{(43)}$ & Rio Grande do Sul, Brasil & Basic Health Units in a low income community & 6 months & A \\
\hline Grassley et al. ${ }^{(44)}$ & Mountain West, United States & Tertiary hospital with joint housing & Not cited & A \\
\hline
\end{tabular}

CASP: Critical Appraisal Skills Programme. 
Regarding the theoretical and methodological aspects, Chart 3 presents the summary of the elements found in the selected articles. Among the methodological frameworks adopted were: ethnography ${ }^{(15-16,21-22,29,31,39)}$, focused ethnography ${ }^{(19-20,31)}$, institutional ethnography $y^{(24,34-35,40-41,44)}$ and ethnonursing ${ }^{(17-18,23,25-28,32-33,36-38,42-43)}$.

Chart 3 - Theoretical and methodological aspects of ethnographic research in obstetric nursing.

\begin{tabular}{|c|c|c|}
\hline \multicolumn{2}{|r|}{ Aspects } & Elements found in the studies \\
\hline \multirow{7}{*}{ Theoretical } & \multirow{7}{*}{$\begin{array}{l}\text { Interpretative Paradigm, } \\
\text { Constructivist Epistemology } \\
\text { and Inductive Logic }\end{array}$} & $\begin{array}{l}\text { Theoretical formulations or concepts in light of the Theory of Diversity and Universality of } \\
\text { Cultural Care }(17-18,23,25,28,32,36-39)\end{array}$ \\
\hline & & Cultural anthropology ${ }^{(15,21)}$, of health and symbolic ${ }^{(27)}$ \\
\hline & & $\begin{array}{l}\text { Pedagogical principles of education for social change in the concept of nursing practice as a } \\
\text { partnership to transform health behaviors }{ }^{(29)}\end{array}$ \\
\hline & & Approach to the four fundamental principles of health ethics ${ }^{(16)}$ \\
\hline & & $\begin{array}{l}\text { Conceptual models of Critical Success Factors and Critical Success Factors and the Model for } \\
\text { the Evaluation of Rural Sustainability }{ }^{(24)}\end{array}$ \\
\hline & & Analytical framework of habitus, capital and the field ${ }^{(20)}$ \\
\hline & & Therapeutic Narratives ${ }^{(26)}$ \\
\hline \multirow{17}{*}{ Methodological } & Referentials & $\begin{array}{l}\text { Ethnography }^{(15-16,21-22,29,31,39)}, \text { focused ethnography }{ }^{(19-20,31)} \text {, institutional ethnography }{ }^{(24,34-35,40-41,44)} \\
\text { and ethnonursing }{ }^{(17-18,23,25-28,32-33,36-38,42-43)}\end{array}$ \\
\hline & \multirow{2}{*}{ Informants } & $\begin{array}{l}\text { Mid-level nursing workers }{ }^{(16,26-27,29)} \text {, teaching nurses, managers and/or care nurs } \\
\text { es }^{(16,20,22,24,31,34-35,37,43-44),} \text { doctors }{ }^{(24)} \text {, midwives }{ }^{(16,31),} \text { administrators }{ }^{(24)} \text {, and other staff }{ }^{(17)}\end{array}$ \\
\hline & & $\begin{array}{l}\text { Pregnant women } \\
\text { family members }{ }^{(17,25-26,37,39)}, \text { friends }^{(17,25)}, \text { companions }^{(25)} \text { and community } \\
\text { far) }\end{array}$ \\
\hline & \multirow{2}{*}{ Scenarios } & $\begin{array}{l}\text { Hospitals, Maternities, Nursing Homes, Clinics and Family Health Cente } \\
\operatorname{rs}^{(15-17,19-20,22,24-32,34-35,38,44)}\end{array}$ \\
\hline & & Households $^{(17,21,33,37,39-41)}$ and communities ${ }^{(18,21,23,36,42)}$ \\
\hline & Obstetric events & $\begin{array}{c}\text { Childbirth }^{(16,19-20,22,24-25,28,30-31,34-35,39-41)}, \text { pregnancy }^{(15,17,21,23,32-33,38,42-43)} \text { and post- } \\
\text { partum }^{(18-19,26-27,29,36-37,44)}\end{array}$ \\
\hline & \multirow{4}{*}{ Data collection techniques } & $\begin{array}{l}\text { Participant }^{(15,21-22,26-27,29,31-32,37,39)} \text { and non- participant }{ }^{(16,30)} \text { observation }^{(20,33-35,38,44)} ; \text { structured }^{(43)} \\
\text { and non-structured }\end{array}$ \\
\hline & & $\begin{array}{l}\text { The Observation-Participation-Reflection Model }{ }^{(17-18,23,25,28,42-43)} \text {, the Stranger-Friend } \\
\text { Model }^{(17-18,25,28)} \text {, acculturation }{ }^{(18)} \text { and the Sunrise Model }{ }^{(17-18,37-38)}\end{array}$ \\
\hline & & 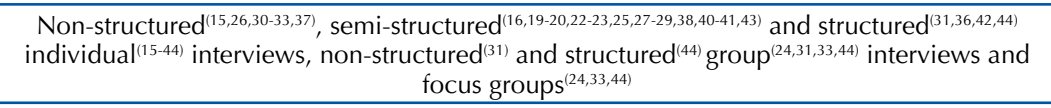 \\
\hline & & 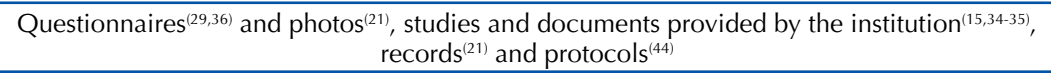 \\
\hline & \multirow{4}{*}{$\begin{array}{l}\text { Data organization and } \\
\text { processing }\end{array}$} & $\begin{array}{c}\text { Topics }^{(15,17-18,21,23,30-33,37-38,44)} \text { and subtopics } \\
\text { cultural }^{(15,18,32,38)} \text {, denominated cultural }{ }^{(23)} \text {, central } \\
\text {, main cultural }{ }^{(38)} \text {, } \text { universal }^{(17)} \text { and cultural descriptors }{ }^{(23)}\end{array}$ \\
\hline & & $\begin{array}{c}\text { Categories }^{(16,21-22,25-28,36,39-41)} \text { and subcategories } \\
\text { thematics }^{(25,28,39-41)} \text {, classified into analytics }^{(21,36)} \text { and }\end{array}$ \\
\hline & & Descriptively from the empirically emerging patterns ${ }^{(19-20,24,29,34-35,43)}$ \\
\hline & & $\begin{array}{l}\text { Leininger-Templin-Thompson Ethno Script Qualitative Software }{ }^{\circledR(17)}, \text { Ethnograph }^{\circledR(18)}, \text { Nudist }^{\circledR(19)} \\
\text { and Atlas.ti }{ }^{\circledR(31)} \text { programs }\end{array}$ \\
\hline & Data analysis & $\begin{array}{l}\text { Ethnonursing }{ }^{(17-18,25-28,36-38,42-43)} \text {, Componential ethnographic analysis }{ }^{(15,32-33)} \text {, Content } \\
\text { analysis }{ }^{(16,21,30-31,40-41,44)}, \text { Framework habitus, capital and the field }{ }^{(20)} \text {, modeling of the } \\
\text { ethnographic decision tree }{ }^{(29)} \text {, analytical method in institutional ethnography }{ }^{(34-35)} \text {, narrative } \\
\text { analysis }{ }^{(22-23)} \text {, grounded theory }{ }^{(30)} \text {, convergent-care analysis }{ }^{(39)} \text {, conceptual models of Critical } \\
\text { Success Factors and Critical Success Factors and the Model for the Evaluation of Rural } \\
\text { Sustainability }{ }^{(24)} \text { and document analysis }{ }^{(15,21)}\end{array}$ \\
\hline & \multirow{2}{*}{$\begin{array}{l}\text { Ethical aspects and } \\
\text { methodological rigor }\end{array}$} & $\begin{array}{l}\text { Ethnonursing criteria: credibility, verifiability, recurring patterns, meaning in context, } \\
\text { saturation and transferability }{ }^{(17-18,26)}, \text { as well as verification and validation of information } \\
\text { collected from informants }{ }^{(19,21-23,29,31)}, \text { credibility }^{(19,22)} \text { and reliability }{ }^{(29)}\end{array}$ \\
\hline & & $\begin{array}{l}\text { Approval by Research Ethics Committees }{ }^{(16,19,21-22,24-29,31-36,38-44)} \text { and signing the Informed } \\
\text { Consent Form }\end{array}$ \\
\hline
\end{tabular}

The main informants were nursing workers ${ }^{(16,20,22,24,26-27,29}$, 31,34-35,37,43-44), pregnant women ${ }^{(15,17,21,23,32-33,42)}$, parturients $^{(25,28,30)}$, postpartum women ${ }^{(18-19,37)}$ and mothers ${ }^{(36,40-41)}$. These participants were key informants or general informants and were included individually, in groups and/or in association. The number of informants ranged from $4^{(42)}$ to $126^{(20)}$, with an average of 20 participants, selected by previously established criteria or intentionally.

The investigations took place in institutional $^{(15-17,19-20,22,24-32,34-35,38,44)}$ and household ${ }^{(17,21,33,37,39-41)}$ and community contexts ${ }^{(18,21,23,36,42)}$. Regarding the duration of the field immersion process, it was observed that although eight studies ${ }^{(15,18,23-24,29,33,37,44)}$ did not specify the duration or period, there was a variation of 12 visits of approximately 6 hours each ${ }^{(16)}$ to 48 months $^{(34-35)}$, with the most frequent being 3 months ${ }^{(25,28,30,32,42)}$.

Observation ${ }^{(15-16,20-22,26-27,29-35,37-39,43-44)}$ represented the most used data collection technique, recorded in field notes $^{(17-20,31-33,38)}$, general notes ${ }^{(15)}$, in a field diary ${ }^{(21,25-27,37,39,42-43)}$ or a reflective diary ${ }^{(19,30)}$. The interviews ${ }^{(15-44)}$ were complementary ${ }^{(15-37,39-44)}$ and were closed by the theoretical saturation criterion ${ }^{(17-19,23,26,28,32-33,36-37,39-43)}$. Ethno-nursing method training guides ${ }^{(17-18,23,25,28,37-38,42-43)}$ were also used for data collection. 
For the analysis of ethnographic data, some of the studies mainly resorted to ethno-nursing ${ }^{(17-18,25-28,36-38,42-43)}$, as well as to content analysis and thematic analysis. Some authors used software ${ }^{(17-19,31)}$ to assist in organizing and processing qualitative data.

Regarding questions related to methodological rigor, most studies did not consistently describe the role, potential bias or influence of the researcher throughout the conduct of the studies. Even so, application of the six qualitative criteria of the ethno-nursing method was highlighted. The studies made reference to ethical guidelines involving research with human beings.

For the analytical aspects, the studies centered the analyzes on different periods, aspects, phenomena and processes of the reproductive cycle from two dimensions of nursing care: from the perspective of professionals (or etic, which refers to professional nursing knowledge and care) and women (or emic, which refers to the internal knowledge of informants translated by popular care). These different characteristics are summarized in Figure 2.

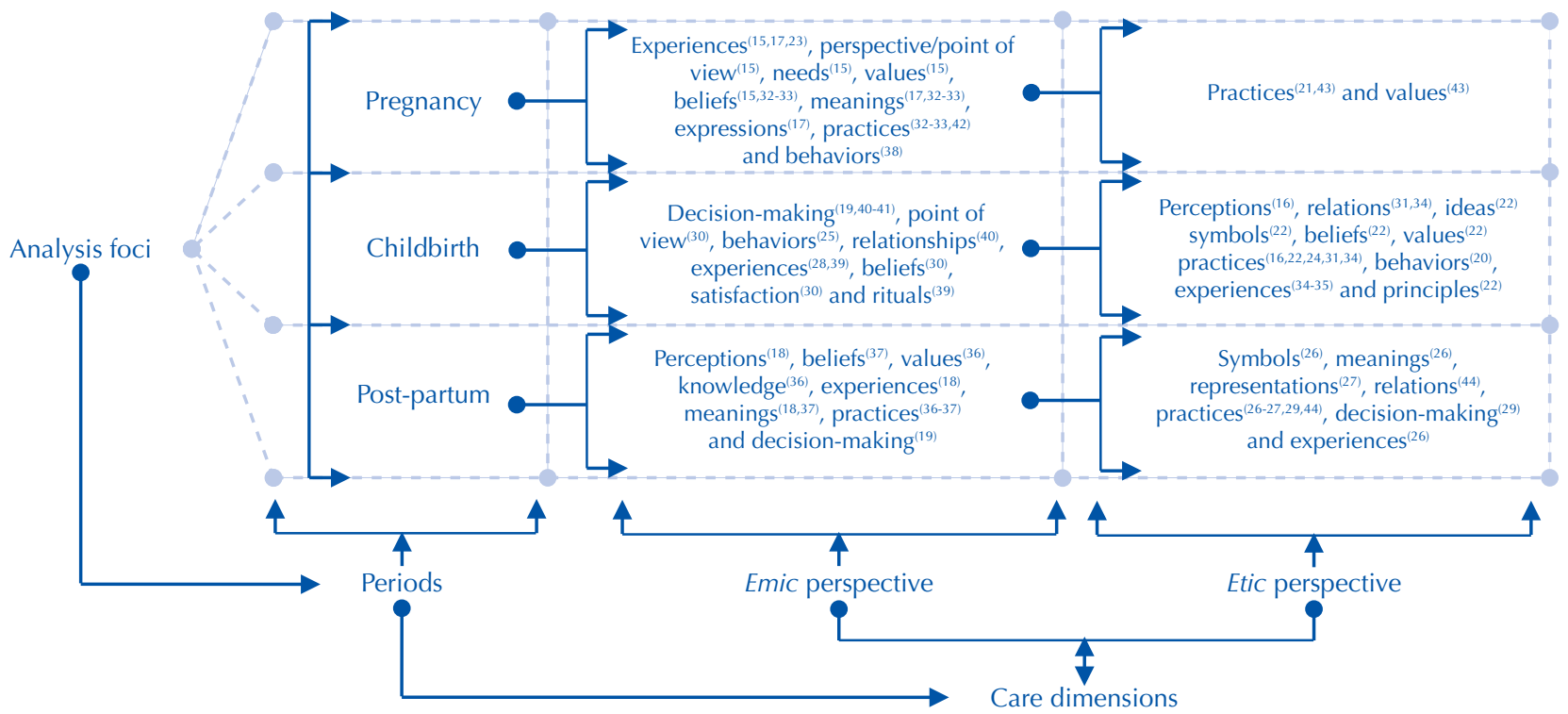

Figure 2 - Distribution of analysis foci by reproductive cycle periods, analysis perspectives and care dimensions adopted in primary studies.

Prenatal analysis foci were used to understand ${ }^{(15,23,42)}$, describe $^{(17,23)}$, explain ${ }^{(17)}$, analyze ${ }^{(17)}$, know $^{(15)}$, discover ${ }^{(32,38)}$ and to explore ${ }^{(33)}$ the sociocultural context and the network of expressions and meanings of women who guided daily praxis and cultural health behaviors, focused on self-care throughout pregnancy. Studies whose analysis focus on nurses sought to know $^{(43)}$ care practices, cultural values and nurses' conceptions by providing care to pregnant women and showing ${ }^{(21)}$ the work process in the social and cultural contexts in which the prenatal care occurred.

Studies conducted during childbirth focused on understanding ${ }^{(25,28,39)}$, exploring ${ }^{(30)}$ or examining ${ }^{(30)}$ ideas, values, beliefs and cultural practices, behaviors, experiences of parturient women and factors which interfered in labor and the delivery, and satisfaction with hospital care during this period, in addition to describing ${ }^{(19)}$ the care acceptance provided by male students in the maternity ward. In contrast, the studies also sought to describe ${ }^{(41)}$ or unveil ${ }^{(40)}$ hesitant sociocultural relationships in daily life as an alternative to the reality of hospital births, which involved the decision-making process of women for planned home births.

They also explored work experiences and the way nurses' institutional discourses, resources, structures and work processes were socially organized, presenting the complexity of professional relationships and a series of overlapping tensions in teamwork ${ }^{(16,20,24,31,34-35)}$. In the context of nursing homes $^{(22)}$, the symbols which permeated the ideas, beliefs, values, practices and principles which guided the care provided in these institutions were identified.

Studies conducted in the postpartum period focused their analysis perspectives to identify ${ }^{(36)}$, discover ${ }^{(18)}$, describe $^{(18,37)}$, discuss ${ }^{(36)}$ or explain ${ }^{(18)}$ personal experiences, knowledge, practices, beliefs, perceptions, meanings and cultural maternal values attributed to caring for oneself and newborn children during the postpartum period. In addition, the decision-making process and acceptance of care provided by male students in postpartum hospital units was described ${ }^{(19)}$. Studies which approached the perspective of professionals sought to: identify ${ }^{(27)}$ or understand ${ }^{(26)}$ the network of symbols and meanings expressed in the experience of nursing workers and the representations they had about culture when developing the care process in joint housing units; to unders$\operatorname{tand}^{(29)}$ decision-making processes; to describe ${ }^{(44)}$ the ability of nursing professionals to offer support to mothers.

\section{DISCUSSION}

Different epistemological, axiological and ontological issues accompany scientific practice and underlie research paradigms ${ }^{(45)}$. Constructivist epistemology and inductivist logic privilege the understanding of subject-object interaction in qualitative research guided by the interpretive paradigm, emphasizing "subjective and sociopolitical meanings as well as symbolic actions in the way people construct and reconstruct their own reality" ${ }^{(45)}$ through social interactions in a given sociocultural context. 
Ethnography stands out among qualitative methods for using a set of values and principles to understand the realities constructed from the subjective experiences of individuals, groups or communities in naturalistic contexts and real world configurations ${ }^{(46-50)}$. Ethnography has been used in health sciences to seek deep cultural knowledge on issues related to care in order to understand people's meanings, perceptions and experiences regarding the health-disease process, the way health behaviors are influenced by culture, work dynamics and health professional relationships ${ }^{(51-52)}$.

In this scope, it is noteworthy that the increasing use and application of ethnography to understand phenomena related to care during the pregnancy-puerperal cycle point to nursing care anthropology, being endorsed through the theoretical-methodological alignment evidenced in studies in this area of obstetric nursing which used the ethno-nursing method associated with the Theory of Diversity and Universality of Cultural Care. This fact reaffirms the importance of recognizing culture as a complex system of mediating meanings between users and professionals within the scope of providing care/receiving care relationships ${ }^{(9,53-54)}$.

Using nursing theories to support studies whose analysis focus on the context of care offered by professionals contributes to developing a structured set of scientific knowledge about human behaviors which are capable of supporting care, teaching and research, so that nursing is strengthened as a profession and discipline ${ }^{(52,54)}$

The choice of the ethnography type denotes that the research interest focuses on specific aspects, contexts and phenomena. While institutional ethnography focuses its attention on the organizational culture of institutions ${ }^{(51)}$, focused ethnography ${ }^{(47)}$ emphasizes the study of shared experiences about a phenomenon confined to a particular culture, subculture, or environments such as obstetric nursing settings ${ }^{(51)}$, and ethno-nursing focuses on specific phenomena related to nursing care ${ }^{(55)}$.

In methodological terms, ethnographic studies in the area of obstetric nursing fall within the spectrum of microethnographies, which encompass relatively short and focused studies. These in turn focus on particular behaviors or a single situation, a specific scenario, multiple social situations or a single social institution with limited duration, which may vary from weeks to months ${ }^{(9,47-49)}$.

Health researchers consider immersion time in the field unimportant and underestimate field notes ${ }^{(51)}$. Although there is no consensus in the literature, there is an indication of permanence for prolonged periods ${ }^{(56)}$ or at least 6 months ${ }^{(57)}$. This enables unveiling and analyzing the complexities and cultural nuances shared in the naturalistic contexts in detail, which is essential to interpret the meaning of the behaviors and phenomena under investigation ${ }^{(9,50)}$.

Thus, depending on the phenomena and the questions which guide the studies, ethnography can be a challenge due to the time spent in the field ${ }^{(57)}$. This aspect may be a possible explanation for the low use of ethnographic methods in nursing, given that part of the studies conducted in the area focus on short-term stricto sensu graduate programs, which limit the immersion time in the field and the theoretical maturity necessary for a thorough understanding of the phenomena ${ }^{(56-57)}$. However, the pregnancy-puerperal cycle has a limited time, leaving researchers a relatively short period to ethnographically investigate the phenomena.

Defining the informants to be observed should occur according to the phenomenon of interest, research domain and the explored questions ${ }^{(9,28)}$. Thus, in this review it was identified that the focus was on women and nursing professionals. Key informants refer to people who experience the investigated phenomenon or know it deeply, being fundamental to grasp and reflect norms, values, beliefs, cultural lifestyles and factors influencing care ${ }^{(3,9)}$. On the other hand, although general informants do not present substantial knowledge or information about the research domain, they have general reflective ideas about the phenomenon under study, providing additional opinions and information from close contact or contact with key informants ${ }^{(3,9)}$.

It is noteworthy that a phenomenon can be investigated with a small number of informants in ethnography since the sample is not prioritized, but the meaning and depth of the statements, the way people experienced the phenomenon, the view of world and the intensity of the relationships established between researcher, informant and research setting ${ }^{(49,58-60)}$.

Although the authors commonly establish inclusion criteria based on characteristics which are common to the participants and driven by the understanding that similarities would provide greater consistency and reliability for the data, reflections may be raised regarding the restrictive and prescriptive character adopted, which would not represent diversity of participants in a given cultural context, nor would it portray the naturalistic context in which the fieldwork took place ${ }^{(49)}$. Thus, although there is no consensus, participants in ethnographic studies are intentionally selected or based on criteria that is inherent to the interlocutor (knowledge, beliefs, roles, ideas, values) which enable them to expose their experiences, providing greater consistency to the investigated phenomenon ${ }^{(49)}$.

Despite the different technical approaches available for data collection, there is no standard indication or procedure for using ethnography due to the recontextualization and diversification that this method has obtained in various scientific disciplines ${ }^{(49,51)}$. Thus, the fieldwork depth, the involvement with the informants in their natural environments and the interpersonal and relational elements give solidity to the findings ${ }^{(48,50-51,61)}$.

Depending on what is intended to be analyzed, observation and participation in the field are central characteristics of ethnographic approaches ${ }^{(46,49,62)}$. Immersion in the scenario seeks an investigation and observation of local language, behaviors, codes and values, assisting in recognizing social practices and processes which develop in a routine, repeated and standardized way as they are accepted and rooted in the social group as cultural elements, thereby constituting objects of analysis and being amenable to second-order interpretations $^{(48-50)}$.

Ethnography generally involves triangulating information obtained from observation, interviews and documentary 
records about the investigated phenomena in order to improve the consistency, validity and reliability of the collected data, as well as guide the researcher in making decisions during the methodological stages ${ }^{(48-49,51-52,62)}$, thus constituting a strategy to give methodological rigor to ethnographic research $^{(51)}$. In addition to these traditional techniques, the ethno-nursing method offers tools which act as enabling guides to facilitate fieldwork ${ }^{(9)}$.

Participant observation appears as the most used data collection technique in obstetric nursing ethnographic studies. This technique enables researchers to be immersed in scenarios, contexts and relationships in which the informants are inserted ${ }^{(48,50,62)}$. Researchers commonly use field diaries to make dense and detailed descriptions of phenomena by recording observations, situations and cultural meanings expressed in everyday manifestations $s^{(9,62-65)}$.

In the context of obstetric nursing, these records enable describing both the performance of the nursing staff, their interactions and manifestations, as well as the daily lives of people who experience the phenomena. In this sense, observations without predetermined scripts are useful for investigating and exploring phenomena in their entirety, providing denser descriptions ${ }^{(9,63-65)}$.

The complementarity character ${ }^{(50)}$ attributed to the interviews enables exploring and deepening previously observed situations and manifestations, and to improve or discard observational interpretations, being an important resource for obtaining data on the informant's view of the investigated phenomenon ${ }^{(3,66-67)}$.

This information can be collected by unstructured informal interviews, which allow the researcher to clarify aspects that emerged during the observation, as well as formal interviews which help clarify the domains and central factors in the study, understand experiences and socio-cultural dimensions, and develop theoretical explanations for the meanings attributed by the informants ${ }^{(9,52)}$.

The in-depth open individual interviews stand out among the types of interviews, which favor collecting complementary data rooted in cultural descriptions and recognizing logical connections between the ideas presented by the informant and those which need more detail due to the participants' freedom of response on a given topic ${ }^{(52)}$. Based on this, theoretical saturation criterion of the collected data is generally used in which the obtained information reaches exhaustion and/or there is data repetition ${ }^{(9,50,58-60)}$.

The use of these associated data collection techniques enables confronting the findings from the observational descriptions in the operative plane and through the verbal reports in the discursive plane. The interface between observations and discourses results in the reflexive nature of ethnography from understanding reality as a complex product permeated by significances, meanings, and multiple perceptions constructed through interactions between researchers and informants, and that the use of various methods captures broad data and diverse from etic (professional) and emic (women) perspectives ${ }^{(9,49)}$.

In ethnographic research, it is prevalent in the literature that researchers constitute the main instrument for data collection $^{(9,48-50,56)}$. Although these include methodical and detailed approaches to field immersion and observation which give methodological rigor to the data collection stage and advocate a neutral stance towards the observed culture, it should be avoided that the scientific findings under study conflict and/or overlap with the researchers' subjective reflections, perspectives, feelings, and opinions on the informants' culture $^{(46,62)}$.

In axiological terms "interpretativism assumes that the researcher never has a neutral position, but that their presuppositions, beliefs, values and interests always intervene in modeling their investigations" ${ }^{\prime(45)}$. In addition, there is a dynamic and mutual influence between the researcher and the research field ${ }^{(51)}$. These two aspects require researchers to assess their influence on findings and data analysis processes in detail ${ }^{(50,56)}$.

Thus, epistemological and personal reflexivity is a central element of ethnographic research insofar as it is based on the assumption that researchers cannot distance themselves or completely detach themselves from their values, beliefs and perceptions in conducting an analysis, and a continuous reflection process which allows them to recognize themselves as dimensions which affect the phenomena, the methodological design and the obtained results is essential $l^{(9,46,48,56)}$.

In this sense, the ethnographic description allows researchers to explicitly expose aspects that may influence the interpretation of data ${ }^{(51)}$. This practice becomes important when researchers share informants' values and perspectives, the investigated contexts are familiar to them, or if they are aware of local routines and codes ${ }^{(9,56)}$.

Fieldwork in various contexts, immersion in various events and experiences, involvement with people who share their lives, routines and conditions to which they are subjected $^{(61)}$, as well as meeting existing hierarchies between different groups of professionals and the need not to interrupt routines and protocols, the transformation of the exotic into the familiar and the familiar into the exotic, the assumption of the role of an insider to gain privileged information, going beyond mere description and unveiling the implicit, the behavioral changes of the informants resulting from the researchers' observation (the Hawthorne effect) and the search for trust in the research setting are implied challenges in the ethnographic making ${ }^{(9,48,50,56,57)}$.

As data collection in ethnographic research takes place in a natural environment, researchers are immersed in the field and establish close relationships with informants, and so ethical dilemmas may arise. Thus, researchers should be aware of the analytical pretensions around the object under study, the roles played, and be attentive to establishing transient relationships and to the construction of trust in order to gain a broader view of the phenomena ${ }^{(49,51)}$.

Due to the constant movement, delimiting the study scenario is essential to control the observation of non-consented persons, which can lead to decision-making about the use of field records ${ }^{(49,51)}$. However, despite efforts to address ethical issues in research involving human subjects, it is observed that researchers in ethnographic research have 
little discussion of the dilemmas and ethical implications they had to deal with while conducting fieldwork ${ }^{(51)}$.

Regarding the data analysis process in ethnographic studies of obstetric nursing, there was a predominance of the ethno-nursing analysis guide, as well as content analysis and thematic analysis. Due to the amplitude, dynamicity, complexity and simultaneity of events that take place in the field, the organization process and analysis of empirical data in ethnonursing requires continuous deepening of the observed situations to grasp the meanings, establish interpretative and reflective categories about the object under study, and confer methodological rigor and soundness to the results ${ }^{(3)}$.

Thus, the researcher should use description, interpretation and critical analysis procedures ${ }^{(9,52)}$ as information is collected to seek meanings from recurrent textual patterns ${ }^{(9,51)}$. These findings are grouped into categories or themes ${ }^{(50)}$ based on a consistent analysis of the phenomenon, thus avoiding the mere description of excerpts and/or speech clippings, which may imply misrepresenting meanings and/ or (mis)interpreting statements by informants.

In this process, researchers need to avoid "imposing categories for the empirical study of a phenomenon" ${ }^{(45)}$ and entering the field "with a predefined set of constructs or instruments to measure reality" ${ }^{(45)}$ based on the assumption that these emerge from performing ethnographic research in the field.

It is noteworthy that it is permitted to use native words, expressions, concepts and images ${ }^{(45)}$; however, ethnographic researchers need to focus on contextual data observed in the field as much as they focus on the textual components that emerge from the interviews ${ }^{(51)}$ in order to provide explanations of how phenomena, actions, and interactions occur in a given cultural setting ${ }^{(50)}$.

Beyond the "crude description" which involves conducting ethnographic research in the field, there must be an intellectual effort by researchers to consider symbolic meanings and to perceive, interpret and make sense of cultural events, actions and behaviors through theoretical ideas, concepts or assumptions ${ }^{(46,52,57)}$. It is an ethnographic look oriented and theoretically sensitized; otherwise, researchers may be biased, limiting analysis to their field experiences and relationships, as well as their personal beliefs and values ${ }^{(9,52,57)}$.

In the context of obstetric nursing care, the use of theoretical and methodological frameworks based on cultural anthropology to ground and base the empirical data enables: knowing the socio-cultural insertion, the influence of beliefs, customs and values on health-related behaviors; unveiling perceptions, experiences and meanings attributed by pregnant women, parturients and postpartum women; and describing the work process of professionals ${ }^{(7,68)}$.

It also enables the unveiling of professional and/or popular care systems from the point of view of individuals who experience the phenomena ${ }^{(3)}$. When accessing the feelings and experiences which emerge from the cultural context of pregnancy and childbirth, one can understand the phenomena related to obstetric care in their complexity from the etic (professional) and emic (women) perspectives ${ }^{(54,66)}$.

Considering the vast field of knowledge of nursing research, this review presents a limitation of its focus being on the obstetric nursing area, as well as having been conducted in four databases and a virtual library. However, the researchers' decision to not include a time frame represents a study potential, as it provides a comprehensive view of using ethnographic approaches in nursing research over time. In addition, discussions of this order contribute to the theoretical-methodological expansion of nursing, as they present characteristics, issues and processes which are inherent to performing ethnographic research that may assist researchers in applying this method in planning, operationalizing and conducting future investigations.

\section{CONCLUSION}

This review enabled demonstrating the theoretical, methodological and analytical aspects of using ethnography in studies involving obstetric nursing. In its methodological aspects, the research conducted in this knowledge area is located around microethnographies. The methodological frameworks used (ethnography, ethnonursing and institutional ethnography) were useful to analyze the complexity of events and phenomena involving obstetric nursing care focusing on the etic (professional) and emic (women) perspectives amidst a diversity of scenarios (institutional) and informants (mainly women and nursing professionals). Still, there was a predominance in the use of theoretical nursing references (Theory of Diversity and Universality of Cultural Care), as well as theories borrowed from other knowledge areas with greater concentration in anthropology.

Ethnography emerges as a relevant method for research in obstetric nursing, as it enables a thorough understanding of the gestation, childbirth and delivery processes, as well as the care offered by nursing professionals in these events, thus contributing to materialize an anthropology of nursing care and enhancing the construction and consolidation of nursing as an art, science and discipline.

\section{RESUMO}

Objetivo: Caracterizar as pesquisas etnográficas na área de enfermagem obstétrica quanto a seus aspectos teóricos, metodológicos e analíticos. Método: Revisão integrativa realizada nas bases de dados MEDLINE ${ }^{\circledR}$, LILACS, BDENF e CINAHL, bem como na biblioteca virtual SciELO. Resultados: Após processo de triagem e leitura na íntegra das referências primárias, 30 artigos formaram o corpus analítico. Os métodos mais utilizados foram etnoenfermagem, etnografia e etnografia institucional; o tempo de imersão no campo variou entre 12 visitas e 48 meses, ocorrendo em contextos institucionais. As principais técnicas de coleta de dados foram observação, entrevistas individuais e guias capacitadores da etnoenfermagem. Os dados foram organizados sob a forma de temas e subtemas, analisados por meio do guia de análise da etnoenfermagem, tendo como referencial teórico a Teoria da Diversidade e Universalidade do Cuidado Cultural. Conclusão: Estudos etnográficos na área de enfermagem obstétrica situam-se no âmbito das microetnografias e são operacionalizados com aporte em referenciais teórico-metodológicos da enfermagem, sendo úteis para se analisar a complexidade dos fenômenos que envolvem o cuidado de enfermagem obstétrico, com foco nas perspectivas etic (profissionais) e emic (mulheres). 


\section{DESCRITORES}

Cuidados de Enfermagem; Enfermagem Obstétrica; Saúde da Mulher; Cultura; Antropologia Cultural; Revisão.

\section{RESUMEN}

Objetivo: Caracterizar las investigaciones etnográficas en el área de enfermería obstétrica en cuanto a sus aspectos teóricos, metodológicos y analíticos. Método: Revisión integrativa llevada a cabo en las bases de datos MEDLINE ${ }^{\circledR}$, LILACS, BDENF y CINAHL, así como en la biblioteca virtual SciELO. Resultados: Tras el proceso de cribado y lectura integral de las referencias primarias, 30 artículos formaron el corpus analítico. Los métodos más utilizados fueron etnoenfermería, etnografía y etnografía institucional; el tiempo de inmersión en el campo varió entre 12 visitas y 48 meses, ocurriendo en contextos institucionales. La principales técnicas de recolección de datos fueron observación, entrevistas individuales y guías capacitadoras de la etnoenfermería. Los datos fueron organizados bajo la forma de temas y subtemas, analizados mediante la guía de análisis de la etnoenfermería, teniendo con marco de referencia teórico la Teoría de la Diversidad y Universalidad del Cuidado Cultural. Conclusión: Estudios etnográficos en el área de enfermería obstétrica se ubican en el marco de las microetnografías y se operacionalizan con aporte en marcos de referencia teóricos metodológicos de la enfermería, siendo útiles para analizarse la complejidad de los fenómenos que involucran el cuidado de enfermería obstétrico, con enfoque en las perspectivas etic (profesionales) y emic (mujeres).

\section{DESCRIPTORES}

Atención de Enfermería; Enfermería Obstétrica; Salud de la Mujer; Cultura; Antropología Cultural; Revisión.

\section{REFERENCES}

1. Costa GM, Gualda DM. Antropologia, etnografia e narrativa: caminhos que se cruzam na compreensão do processo saúde-doença. Hist Ciênc Saúde Manguinhos. 2010;17(4):925-37. DOI: http://dx.doi.org/10.1590/S0104-59702010000400005

2. Müller CP, Araujo VE, Bonilha AL. Possibilidade de inserção do cuidado cultural congruente nas práticas de humanização na atenção à saúde. Rev Eletr Enferm. 2007;9(3):858-65. DOI: https://doi.org/10.5216/ree.v9i3.7513

3. Leininger M. Culture care diversity and universality theory and evolution of the ethnonursing method. In: Leininger M, Mcfarland MR. Culture care diversity and universality: a worldwide nursing theory. $2^{\mathrm{a} e d}$. Sudbury: Jones and Bartlett; 2006. p. 1-41.

4. Eleri J, Samantha RL, Ernestina C. Interventions to provide culturally-appropriate maternity care services: factors affecting implementation. BMC Pregnancy Childbirth. 2017;17(1):267. DOI: https://doi.org/10.1186/s12884-017-1449-7

5. Costa E, Jones E, Portela A, Lattof SR. Maternity care services and culture: a systematic global mapping of interventions. PLoS One. 2014;9(9):e108130. DOI: https://doi.org/10.1371/journal.pone.0108130

6. Newnham EC, McKellar LV, Pincombe JI. Paradox of the institution: findings from a hospital labour ward ethnography. BMC Pregnancy Childbirth. 2017;17(1):2. DOI: https://doi.org/10.1186/s12884-016-1193-4

7. Chibante CL, Santo FH. Etnografía en la investigación en enfermería: una revisión integrativa. Cult Cuid. 2014;18(40):99-106. DOI: http:// dx.doi.org/10.7184/cuid.2014.40.13

8. Flick U. Desenho da pesquisa qualitativa. Porto Alegre: Artmed; 2009.

9. Bourbonnais A. L'ethnographie pour la recherche infirmière, une méthode judicieuse pour mieux comprendre lês comportements humains dans leur context. Rech Soins Infirm. 2015;1(120):23-34. DOI: https://doi.org/10.3917/rsi.120.0023

10. Mendes KD, Silveira RC, Galvão CM. Revisão integrativa: método de pesquisa para a incorporação de evidências na saúde e na enfermagem. Texto Contexto Enferm. 2008;17(4):758-64. DOI: http://dx.doi.org/10.1590/S0104-07072008000400018

11. Araujo NB, Mandú EN. Produção de sentidos entre adolescentes sobre o cuidado de si na gravidez. Interface Comun Saúde Educ. 2016;20(57):363-75. DOI: http://dx.doi.org/10.1590/1807-57622015.0301

12. Moher DA, Tetzlaff J, Altman DG; The PRISMA Group. Preferred reporting items for systematic reviews and meta-analyses: the PRISMA Statement. PLoS Med. 2009;6(6):1-6. DOI: https://doi.org/10.1371/journal.pmed.1000097

13. Milton Keynes Primary Care Trust. Critical Appraisal Skills Programme (CASP): making sense of evidence. London: Oxford; 2002.

14. Whittemore R, Knafl K. The integrative review: updated methodology. J Adv Nurs. 2005;52(5):546-53. DOI: https://doi.org/10.1111/j.13652648.2005.03621.x

15. Bonadio IC. Ser tratada como gente: a vivência de mulheres atendidas no serviço de pré-natal de uma instituição filantrópica. Rev Esc Enferm USP. 1998;32(I):9-15. DOI: https://doi.org/10.1590/S0080-62341998000100003

16. Woodward VM. Caring, patient autonomy and the stigma of paternalism. J Adv Nurs. 1998;28(5):1046-52. DOI: https://doi.org/10.1046/ j.1365-2648.1998.00741.x

17. Berry AB. Mexican American women's expressions of the meaning of culturally congruent prenatal care. JTranscult Nurs. 1999;10(3):20312. DOI: https://doi.org/10.1177/104365969901000311

18. Nahas $\mathrm{V}$, Nawal A. Culture care meanings and experiences of postpartum depression among Jordanian Australian women: a transcultural study. J Transcult Nurs. 1999;10(1):37-45. DOI: https://doi.org/10.1177/104365969901000113

19. Morin KH, Patterson BJ, Kurtz B, Brzowski B. Mothers' responses to care given by male nursing students during and after Birth. Image J Nurs Scholarsh. 1999;31(1):83-7. DOI: https://doi.org/10.1111/j.1547-5069.1999.tb00426.x

20. Angus J, Hodnett E, O'Brien-Pallas L. Implementing evidence-based nursing practice: a tale of two intrapartum nursing units. Nurs Inq. 2003;10(4):218-28. DOI: https://doi.org/10.1046/j.1440-1800.2003.00193.x

21. Praça NS. Pesquisa qualitativa, ensino e assistência de enfermagem: interação que favorece o cuidado cultural. Cienc Enferm. 2003;9(2):6775. DOI: http://dx.doi.org/10.4067/S0717-95532003000200007

22. Hoga LA. Casa de parto: simbologia e princípios assistenciais. Rev Bras Enferm. 2004;57(5):537-40. DOI: http://dx.doi.org/10.1590/ S0034-71672004000500004 
23. Jeneral RB, Hoga LA. A incerteza do futuro: a vivência da gravidez em uma comunidade brasileira de baixa renda. REME Rev Min Enferm [Internet]. 2004 [citado 2019 jan. 8];8(2):268-74. Disponível em: http://www.reme.org.br/artigo/detalhes/735

24. Medves JM, Davies BL. Sustaining rural maternity care--don't forget the RNs. Can J Rural Med. 2005;10(1):29-35.

25. Bezerra MG, Cardoso MV. Fatores interferentes no comportamento das parturientes: enfoque na etnoenfermagem. Rev Bras Enferm. 2005;58(6):698-702. DOI: http://dx.doi.org/10.1590/S0034-71672005000600013

26. Monticelli M, Elsen I. When the narrative period lasts longer than clinical period: a method for post-natal nursing care. Texto Contexto Enferm. 2005;14(2):167-76. DOI: http://dx.doi.org/10.1590/S0104-07072005000200003

27. Monticelli M, Elsen I. Culture as an obstacle: perceptons in nursing towards care for the family in multiple-patient rooms. Texto Contexto Enferm. 2006;15(1):26-34. DOI: http://dx.doi.org/10.1590/S0104-07072006000100003

28. Bezerra MG, Cardoso MV. Fatores culturais que interferem nas experiências das mulheres durante o trabalho de parto e parto. Rev Latinoam Enferm. 2006;14(3):414-21. DOI: http://dx.doi.org/10.1590/S0104-11692006000300016

29. Foster J, Regueira Y, Heath A. Decision making by auxiliary nurses to assess postpartum bleeding in a Dominican Republic maternity ward. J Obstet Gynecol Neonatal Nurs. 2006;35(6):728-34. DOl: http://dx.doi.org/10.1111/j.1552-6909.2006.00096.x

30. El-Nemer A, Downe S, Small N. 'She would help me from the heart': an ethnography of Egyptian women in labour. Soc Sci Med. 2006;62:81-92. DOI: http://dx.doi.org/10.1016/j.socscimed.2005.05.016

31. Kennedy HP, Lyndon A. Tensions and teamwork in nursing and midwifery relationships. J Obstet Gynecol Neonatal Nurs. 2008;37(4):42635. DOI: http://dx.doi.org/10.1111/j.1552-6909.2008.00256.x

32. Leal DP, Rodríguez LM. La condición materna y el ejercicio en la gestación favorecen el bienestar del hijo y el parto. Av Enferm [Internet]. 2008 [citado 2019 jan. 8];26(2):51-8. Disponible en: https://revistas.unal.edu.co/index.php/avenferm/article/view/12898/13658

33. Bernal-Roldán MC, Rodríguez LM, Cárdenas $\mathrm{CH}$. Significado del cuidado de si y de su hijo por nacer en gestantes desplazadas. Aquichan [Internet]. 2009 [citado 2019 jan. 28];8(1):97-115. Disponible en: http://aquichan.unisabana.edu.co/index.php/aquichan/article/ view/127/255

34. MacKinnon K. Rural nurses' safeguarding work reembodying patient safety. Adv Nurs Sci. 2011;34(2):119-29. DOI: http://dx.doi. org/10.1097/ANS.0b013e3182186b86

35. MacKinnon K. We cannot staff for 'what ifs': the social organization of rural nurses' safeguarding work. Nurs Inq. 2012;19(3):259-69. DOI: https://doi.org/10.1111/j.1440-1800.2011.00574.x

36. Maia SM, Silva LR. Saberes e práticas de mães ribeirinhas e o cuidado dos filhos recém-nascidos: contribuição para a enfermagem. Rev Enf Ref. 2012;7(3):131-8. DOI: http://dx.doi.org/10.12707/RIII11130

37. Prieto BB, Ruiz CH. Significados durante el puerperio: a partir de prácticas y creencias culturales. Aquichan [Internet]. 2013 [citado 2019 jan. 8];13(1):7-16. Disponible en: http://www.scielo.org.co/pdf/aqui/v13n1/v13n1a02.pdf

38. Tasçı-Duran E, Sevil U. A Comparison of the prenatal health behaviors of women from four cultural groups in Turkey: an ethnonursing study. Nurs Sci Q 2013;26(3):257-66. DOI: https://doi.org/10.1177/0894318413489180

39. Feyer IS, Monticelli M, Boehs AE, Santos EK. Rituais de cuidado realizados pelas fa mílias na preparação para a vivência do parto domiciliar planejado. Rev Bras Enferm. 2013;66(6):879-86. DOI: http://dx.doi.org/10.1590/S0034-71672013000600011

40. Lessa HF, Tyrell RM, Alves VH, Rodrigues DP. Social relations and the option for planned home birth: an institutional ethnographic study. Online Braz J Nurs [Internet]. 2014 [cited 2019 Jan 9];13(2):239-49. Available from: http://www.objnursing.uff.br/index.php/nursing/ article/view/4163/html_121

41. Lessa HF, Tyrrell MA, Alves VH, Rodrigues DP. Information for the option of planned home birth: women's right to choose. Texto Contexto Enferm. 2014;23(3):665-72. DOI: http://dx.doi.org/10.1590/0104-07072014000930013

42. Junges CF, Ressel LB, Monticelli M. Amongst wishes and possibilities: eating habits of pregnant women from an urban community in Southern Brazil. Texto Contexto Enferm. 2014;23(2):382-90. DOI: http://dx.doi.org/10.1590/0104-07072014000210013

43. Alves CN, Wilhelm LA, Barreto CN, Santos CC, Meincke SM, Ressel LB. Cuidado pré-natal e cultura: uma interface na atuação da enfermagem. Esc Anna Nery Rev Enferm. 2015;19(2):265-71. DOI: 10.5935/1414-8145.20150035

44. Grassley JS, Clark M, Schleis J. An institutional ethnography of nurses' support of breastfeeding on the night shift. J Obstet Gynecol Neonatal Nurs. 2015;44(5):567-77. DOI: http://dx.doi.org/10.1111/1552-6909.12728

45. Saccol AZ. Um retorno ao básico: compreendendo os paradigmas de pesquisa e sua aplicação na pesquisa em Administração. Rev Adm UFSM [Internet]. 2009 [citado 2019 jan. 8];2(2):250-69. Disponível em: https://periodicos.ufsm.br/reaufsm/article/view/1555/863

46. Ryan GS. An introduction to the origins, history and principles of ethnography. Nurse Res. 2017;24(4):15-21. DOI: http://dx.doi. org/10.7748/nr.2017.e1470

47. Cruz EV, Higginbottom G. The use of focused ethnography in nursing research. Nurse Res. 2015;20(4):36-43. DOI: http://dx.doi. org/10.7748/nr2013.03.20.4.36.e305

48. Draper J. Ethnography: principles, practice and potential. Nurs Stand. 2015;29(36):36-41. DOI: http://dx.doi.org/10.7748/ns.29.36.36. e8937

49. Lambert V, Glacken M, McCarron M. Employing an ethnographic approach: key characteristics. Nurse Res. 2011;19(1):17-23. DOI: http:// dx.doi.org/10.7748/nr2011.10.19.1.17.c8767

50. Jones J, Smith J. Ethnography: challenges and opportunities. Evidence Based Nurs. 2017;20(4):98-100. DOI: http://dx.doi.org/10.1136/ eb-2017-102786

51. Rashid M, Caine V, Goez H. The Encounters and Challenges of Ethnography as a Methodology in Health Research. Int J Qual Methods. 2015:14(5):1-16. DOI: https://doi.org/10.1177/1609406915621421 
52. Robinson SG. The relevancy of ethnography to nursing research. Nurs Sci Q. 2013;26(1):14-9. DOI: https://doi. org/10.1177/0894318412466742

53. Morais AC, Camargo CL, Quirino MD. A etnografia nas pesquisas de enfermagem com ênfase no cuidado. Cogitare Enferm. 2011;16(3):54955. DOI: http://dx.doi.org/10.5380/ce.v16i3.17807

54. Monticelli M, Boehs AE, Guesser JC, Gehrmann T, Martins M, Manfrini GC. Transcultural Theory applications in nursing practice from master's theses. Texto Contexto Enferm. 2010;19(2):220-8. DOI: http://dx.doi.org/10.1590/S0104-07072010000200002

55. Molloy L, Walker K, Lakeman R. Shared worlds: multi-sited ethnography and nursing research. Nurse Res. 2017;24(4):22-6. DOI: https:// doi.org/10.7748/nr.2017.e1506

56. Gelling L. Complexities of ethnography. Nurse Res. 2014;22(1):6-7. DOI: https://doi.org/10.7748/nr.22.1.6.s2

57. Melo LP, Stofel NS, Gualda D, Campos EA. Nurses' experiences of ethnographic fieldwork. Nurse Res. 2014;22(1):14-19. DOI: https:// doi.org/10.7748/nr.22.1.14.e1243

58. Rosa, NG, Lucena AF, Crossetti MG. Etnografia e etnoenfermagem: métodos de pesquisa em enfermagem. Rev Gaúcha Enferm [Internet]. 2003 [citado 2019 jan. 8];24(1):14-22. Disponível em: http://seer.ufrgs.br/index.php/RevistaGauchadeEnfermagem/article/view/4433/2359

59. Sant'Ana RB. A implicação do pesquisador na pesquisa interacionista na escola. Psicol Rev (Belo Horizonte). [Internet]. 2010 [citado 2019 jan. 8];16(2):370-87. Disponível em: http://pepsic.bvsalud.org/pdf/per/v16n2/v16n2a09.pdf

60. Sousa LB, Barroso MG. Pesquisa etnográfica: evolução e contribuição para a enfermagem. Esc Anna Nery Rev Enferm. 2008;12(1):150-5. DOI: http://dx.doi.org/10.1590/S1414-81452008000100023

61. Patterson C, Procter N, Toffoli L. Nursing and the ethnographic accomplishment. Nurse Res. 2017;24(4):6-7. DOI: https://doi.org/10.7748/ nr.24.4.6.s2

62. Conroy T. A beginner's guide to ethnographic observation in nursing research. Nurse Res. 2017;24(4):10-4. DOI: https://doi.org/10.7748/ nr.2017.e1472

63. Emerson RM, Fretz RI, Shaw LL. Notas de campo na pesquisa etnográfica. Cad Ciênc Soc [Internet]. 2013 [citado 2019 jan. 8];7(1):355-88. Disponível em: http://periodicos.urca.br/ojs/index.php/RevTendenc/article/view/690/606

64. Trad LA. Trabalho de campo, narrativa e produção de conhecimento na pesquisa etnográfica contemporânea: subsídios ao campo da saúde. Ciênc Saúde Colet. 2012;17(3):627-33. DOI: http://dx.doi.org/10.1590/S1413-81232012000300008

65. Nunes GB, Nogueira LT. Culture and care: literature review on the ethnographic method in the nursing researches. Rev Enferm UFPE Online [Internet]. 2011 [cited 2019 Jan 9];5(8):2038-45. Available from: https://periodicos.ufpe.br/revistas/revistaenfermagem/article/ viewFile/6894/6143

66. Silveira RS, Martins CR, Lunardi VL, Lunardi-Filho WD. Etnoenfermagem como metodologia de pesquisa para a congruência do cuidado. Rev Bras Enferm. 2009;62(3):442-6. DOI: http://dx.doi.org/10.1590/S0034-71672009000300017

67. Nakamura E. O método etnográfico em pesquisas na área da saúde: uma reflexão antropológica. Saúde Soc. 2011;20(1):95-103. DOI: http://dx.doi.org/10.1590/S0104-12902011000100012

68. Lenardt MH, Michel T, Melo LP. As pesquisas etnográficas em enfermagem nas sociedades complexas. Colomb Med [Internet]. 2011 [citado 2019 jan. 8];42(2):70-7. Disponível em: http://www.bioline.org.br/pdf?rc11042 